J. Product. \& Dev., 16(3):345 - 367(2011)

\title{
INFLUENCE OF SOAKING CLOVES OF BALADY AND CHINESE GARLIC CULTIVARS IN SOME MICRONUTRIENTS SOLUTIONS ON GROWTH, CHEMICAL COMPOSITION, YIELD, BULB QUALITY AND STORAGEABILITY
}

\author{
Wafaa A. Fekry
}

Plant Production Department, Efficient Productivity Institute, Zagazig

Univeristy, Egypt.

\section{ABSTRACT}

Two field experiments were carried out during the two winters seasons of 2007 / 2008 and 2008/ 2009 at the Experimental Farm, Faculty of Agriculture, Moshtohor Benha University, to study the effect of soaking cloves of both Balady and Chinese garlic cultivars for 24 hours per-planting in solutions of 1000 ppm Mn, 500 ppm Zn or 400 ppm Cu solely or in their possible combinations on plant growth, chemical composition, bulb yield and quality as well as storageability.

Obtained results indicated that, both used cultivars showed significant differences in most of the studied characters. Balady $\mathrm{cv}$. had the best results of some vegetative growth characters (plant height, fresh weight of leaves, neck diameter and bulbing ratio), chemical composition ( $N, p$ and $K$ content of both leaves and bulbs), number of cloves per bulb, bulb quality $(\mathrm{N}, \mathrm{P}, \mathrm{K}, \mathrm{Mn}, \mathrm{Zn}, \mathrm{Cu}$ content and total carbohydrates percentage of cloves). Whereas, Chinese $c v$. showed the highest values of some vegetative growth parameters, i.e., number of leaves, bulb diameter, dry weight of leaves, bulbs and plant, bulb yield and its components, i.e., fresh weigh and dry matter percentage of bulb, fresh weight of single clove as well as total cured yield per feddan and total soluble solids percentage of bulbs. Furthermore, Chinese cv. showed the least weight loss and diseases infection percentage during storage period for six months.

The micronutrients treatments significantly and positively affected all the studied characters.

From the obtained results, it can be recommended that soaking garlic cloves for 24 hours per-planting in mixture of 1000 ppm Mn+ 400 ppm Cu in case of Balady cv. or in 1000 ppm Mn+500 ppm Zn in case of Chinese cv. to obtain maximum values of most studied variables.

Key words: Soaking cloves, Balady \& Chinese garlic cultivars, micronutrients solutions, growth, chemical composition, yield, bulb quality, storageability 


\section{INTRODUCTION}

Garlic (Allium sativum L.) is one of the most important vegetable crops in Egypt and all over the world. There was a growing demand for garlic products due to the increasing knowledge of garlic benefits to human health. The Balady cultivar was dominating for a long time and still preferable for the local market and for export. On the other hand, an attention was paid to localize several varieties that have better yield and bulb quality. The Chinese cultivar is a softneck variety and is dominating for commercial mass production in several countries around the world. This cultivar dose not produce a seed stalk and show good bulb quality as well as high yield.

Increasing productivity of garlic with good quality is an important aim for the growers. This aim could be achieved through choosing the suitable agricultural practices among them cultivars and fertilization requirements.

In regards to the effect of grown cultivars on garlic growth, yield and its quality, Hassan et al. (1993) reported that Balady $c v$. significantly dominated the Chinese cultivar in the plant height, number of leaves, bulb diameter, number of cloves/bulb and cured yield. On the other hand, El-Sayed (2004) found that Chinese $c v$. surpassed Balady cultivar in number of leaves/plant, bulb diameter, fresh and dry weight of leaves and bulbs, as well as it gave the smallest neck diameter and bulbing ratio.

In most Egyptian soil $\mathrm{pH}$ is often high, thus applying micronutrients such as $\mathrm{Mn}, \mathrm{Zn}$, and $\mathrm{Cu}$ may play an important role for growth and yield of many plants. Simis and Patrick (1978) found that $\mathrm{Fe}, \mathrm{Mn}, \mathrm{Zn}$ and $\mathrm{Cu}$ were lower in the exchangeable fractions at higher $\mathrm{pH}$ than at lower one.

In this respect, many investigators reported the importance of applying $\mathrm{Mn}, \mathrm{Zn}$ and $\mathrm{Cu}$ solely or in combinations on growth, chemical composition of plants, yield and its components, as well as quality and storageability of bulbs (Abed et al., 1988; Abdel-Ati et al., 1993; Ayman, 2002; Abd-El-Moneem et al., 2005 and Nasreen et al., 2009 on garlic and El-Mansi and Sharaf El-Dien, 2005; El-Tohamy et al., 2009 and Alam et al., 2010 on onion.

The aim of this study was to investigate the effect of pre - planting soaking cloves of the widely grown garlic cultivars in Egypt( Balady and Chinese) in micronutrients solutions, i.e., $\mathrm{Mn}, \mathrm{Zn}$ and $\mathrm{Cu}$ each alone or in their possible combinations on growth, chemical composition of plant, yield and its components, as well as, quality and storageability of produced bulbs.

\section{MATERIALS AND METHODS}

Two field experiments were conducted at the Experimental Farm of Faculty of Agriculture, Moshtohor Benha University, Kalubia Governorate during the winters seasons of 2007/2008 and 2008/2009.This study was carried out to investigate the effect of pre-planting soaking garlic cloves cvs Balady 
and Chinese for 24 hours in aqueous solutions of each of Manganese (Mn), Zinc $(\mathrm{Zn})$ and Copper $(\mathrm{Cu})$ or in their possible combinations in "sulphate form" on plant growth, chemical constituents, yield, quality and storageability of garlic bulbs (Allium sativum L.) under clay loam soil conditions.

Mechanical and chemical analysis for experimental soil were carried out using the standard methods mentioned by Jackson (1970) and Black (1982). Data for this respect are show in Table 1.

Table 1: Mechanical and chemical analysis of the experimental soil field during 2007/2008 and 2008/2009 seasons.

\begin{tabular}{ccc}
\hline Soil characteristics & \multicolumn{2}{c}{ Values } \\
\cline { 2 - 3 } & $\mathbf{2 0 0 7 / 2 0 0 8}$ & $\mathbf{2 0 0 8 / 2 0 0 9}$ \\
\hline Mechanical analysis & & \\
Coarse sand (\%) & 7.63 & 7.66 \\
Fine sand (\%) & 16.60 & 16.65 \\
Silt (\%) & 34.55 & 34.71 \\
Clay (\%) & 41.22 & 40.98 \\
Texture class & Clay-loam & Clay-loam \\
Chemical analysis & & \\
pH (soil paste) & 7.5 & 7.6 \\
Organic matter (\%) & 1.85 & 1.79 \\
Available elements (ppm): & & \\
N & 82.70 & 82.50 \\
P & 20.45 & 20.50 \\
K & 280.0 & 278.80 \\
Mn & 8.40 & 8.32 \\
$\mathrm{Zn}$ & 2.75 & 2.60 \\
$\mathrm{Cu}$ & 2.22 & 2.15 \\
\hline
\end{tabular}

Garlic cloves of $c v s$ Balady and Chinese were planted on October $1^{\text {st }}$ and $5^{\text {th }}$ in 2007/2008 and 2008/2009 seasons, respectively. This experiment was set out in a split plot design with four replicates, where garlic cultivars were arranged in the main plots, while micronutrients treatments were distributed randomly in the sub plots. The experiment included sixteen treatments which were the combinations between two garlic cultivars, i.e., Balady and Chinese and eight treatments of micronutrients as follows:

1- Control (tap water).

2- $500 \mathrm{ppm} \mathrm{Zn.}$

3- $400 \mathrm{ppm} \mathrm{Cu}$.

4- $1000 \mathrm{ppm} \mathrm{Mn}$.

5- $1000 \mathrm{ppm} \mathrm{Mn}+500 \mathrm{ppm} \mathrm{Zn}$.

6- $500 \mathrm{ppm} \mathrm{Zn}+400 \mathrm{ppm} \mathrm{Cu}$.

7- $1000 \mathrm{ppm} \mathrm{Mn}+400 \mathrm{ppm} \mathrm{Cu}$.

8- $1000 \mathrm{ppm} \mathrm{Mn}+500 \mathrm{ppm} \mathrm{Zn}+400 \mathrm{ppm} \mathrm{Cu}$. 
All experimental units area was $9.8 \mathrm{~m}^{2}$. Each plot included four ridges (70 $\mathrm{cm}$ width and $3.5 \mathrm{~m}$ long) which were planted, in addition one ridge was left without planting as a guard one between plots. Cloves were planted $7 \mathrm{~cm}$ apart on both sides of ridge

Plants were fertilized with $120 \mathrm{~kg} \mathrm{~N} / \mathrm{fed}$ as ammonium nitrate $(33.5 \%$ $\mathrm{N}), 76 \mathrm{~kg} \mathrm{P}_{2} \mathrm{O}_{5} / \mathrm{fed}$ as calcium superphosphate $\left(15-16 \% \mathrm{P}_{2} \mathrm{O}_{5}\right)$ and $96 \mathrm{~kg}$ $\mathrm{K}_{2} \mathrm{O} /$ fed as potassium sulphate $\left(48 \% \mathrm{~K}_{2} \mathrm{O}\right)$. The amount of NPK fertilizers were divided at three equal portions and added two, three and four months after planting. Other agricultural practices of growing garlic plants were carried out as commonly followed in the district.

\section{Data recorded:}

\section{a. Plant growth characteristics:}

A random sample of ten plants was taken from each experimental plot at 140 days after planting in both seasons of study for measuring plant height, number of leaves, fresh and dry weight of leaves, bulb and plant as well as diameter of neck and bulb. Bulbing ratio was calculated by using the following formula described by Mann (1952).

Bulbing ratio $=$

$$
\text { Maximum neck diameter }
$$

Maximum bulb diameter

\section{b. Plant chemical composition:}

Nitrogen, phosphorus and potassium were determined in the digested dry matter of leaves and bulbs according to the methods described by Bremner and Mulvaney (1982), Olsen and Sommers (1982) and Jackson (1970), respectively.

\section{c- Yield and its components:}

At harvest time (180 days from planting) plants of each experimental unit were harvested and left to be cured for two weeks , then plants were weighed $(\mathrm{kg} / \mathrm{plot})$ and total cured yield of whole plants (ton/fed)was calculated . A random sample of 10 bulbs was taken from each plot to determine:bulb fresh and dry weight, number of cloves / bulb as well as clove fresh weight.

\section{d-Bulb quality:}

At harvest time, a sample $100 \mathrm{~g}$ of cloves from each treatment were oven dried at $70{ }^{\circ} \mathrm{C}$ till constant weight, ground and wet digested to determine total nitrogen, phosphorus and potassium contents according to the same methods described previously in plant chemical composition. Moreover, manganese, zinc and copper contents were determined using the method described by Chapman and Pratt (1961) and total carbohydrates according to 
Dubois et al. (1956). In addition total soluble solids (T.S.S.) was assayed in fresh cloves by using Carl Zeis Refractometer.

\section{e- Storageability:}

Samples of cured garlic bulbs (4 $\mathrm{kg}$ from every experimental plot) in both seasons were placed in nets and stored under normal room conditions (24 ${ }^{0} \mathrm{C} \pm 5{ }^{0} \mathrm{C}$ and $60 \%$ R. H.). In both seasons, the storage zero time was April $20^{\text {th }}$ and the end was October $20^{\text {th }}$. The following data were recorded monthly:

a-Weight loss percentage (\%): Bulb samples of each plot were weighed at 30 day intervals, then the cumulative weight loss percentage was calculated.

b-Infection and rot diseases percentage (\%): it was estimated and expressed as percentage of number of infected bulbs.

\section{Statistical Analysis:}

All the obtained data were subjected to statistical analysis of variance according to Gomez and Gomez (1984). Means separation was done by using L.S.D. at 0.05 level of probability.

\section{RESULTS AND DISCUSSION}

\section{a-Plant growth characteristics:}

\section{1- Effect of cultivars:}

Results in Table 2 reflect significantly differences among Balady and Chinese cultivars in all studied growth characters. Balady cv.excel mostly the Chinese cv. in producing taller plants, fresh weight of leaves per plant, neck diameter and bulbing ratio during both seasons of study. On the other hand, Chinese cv. produced more leaves number per plant, fresh and dry weight of both bulb and plant, as well as bulb diameter during the two seasons of investigation. Moreover, observed small values of neck diameter and bulbing ratio recognized in Chinese $\mathrm{cv}$. may be considered as a favorable character (Mann,1952 and Atwa,1970).

In this respect, Maksoud and El-Oksh,1983and Abd El-Hamied, 1990reported that the differences between cultivars could be due to genetic differences. These results are in agreement with those reported by Zaki (1984), Maksoud et al.(1987), El-Sawah(1990), Ayman(2002) and El-Sayed (2004) all working on garlic.

\section{2- Effect of micronutrients:}

It is evident from data in Table 2 that pre-planting soaking cloves in the solution of test micronutrients, i.e., $\mathrm{Mn}$ at 1000ppm, $\mathrm{Zn} 500$ ppm, $\mathrm{Cu}$ at 400ppm either alone or at their different combinations significantly affected all the studied variables of the vegetative growth during both seasons of study comparing with the control treatment. In general, the most effective treatment was variable according to the growth parameter and season. 
In this concern, the treatment $(1000+400 \mathrm{ppm})$ for $\mathrm{Mn}$ and $\mathrm{Cu}$, respectively in the first season or $\mathrm{Zn}$ at $500 \mathrm{ppm}$ with either $\mathrm{Cu}$ at $400 \mathrm{ppm}$ or $\mathrm{Mn}$ at $1000 \mathrm{ppm}$ in the second one gave the highest values of most characters compared with the other treatments. The increase in vegetative growth parameters of plants treated with micronutrients, i.e., $\mathrm{Mn}, \mathrm{Zn}$ and $\mathrm{Cu}$ can be explained on the basis that, these micronutrients activate the enzymes concerned with the metabolism of N, protein and RNA synthesis (Sauchelli, 1969). Moreover, such stimulative effect may be due to stimulation and increasing production of ouxins in plans tissues which may led to the activation of meristematic tissues (Ancpok, 1990 and Abd- El-Moneem et al., 2005). Obtained results are in conformity with those reported by Abed et al. (1988), Abdel- Ati et al. (1993), Ayman (2002), El-Zohery (2003) and Abd-ElMoneem et al. (2005) all working on garlic.

\section{3- Effect of the interaction between cultivars and micronutrients:}

Data in Table 2 indicate that the interaction between cultivars and micronutrients treatments had significant effect for all studied plant growth characters in both growing seasons, except plant height, number of leaves/plant and bulb fresh weight in the second season only. In this respect, soaking Balady $\mathrm{cv}$. cloves for 24 hours before planting in solutions containing (1000 ppm Mn $+400 \mathrm{ppm} \mathrm{Cu})$ or $(500 \mathrm{ppm} \mathrm{Zn}+400 \mathrm{ppm} \mathrm{Cu})$ were the best treatments, meanwhile, Chinese cv. achieved superior results when cloves were soaked in solutions of ( $1000 \mathrm{ppm} \mathrm{Mn}+500 \mathrm{ppm} \mathrm{Zn})$ compared with other treatments. All these results either for Balady or Chinese cultivars were changed according to the growth parameters and season. These results are in harmony with those reported by Abed et al. (1988), Abdel-Ati et al.(1993), Ayman (2002) and ElZohery (2003) on garlic.

\section{b-Plant chemical composition:}

\section{1- Effect of cultivars:}

Data illustrated in Table 3 indicate that Balady cultivar exhibited significantly the highest values of nitrogen, phosphorous and potassium content of leaves and bulbs compared with Chinese cultivar during both growing seasons. The differences between cultivars in minerals content could be due to genetic factors of cultivars (Maksoud and El-Oksh, 1983). These results agree with those reported by Nurzynska and Wierdak (1997) and El-Sayed (2004) on garlic.

\section{2- Effect of micronutrients:}

Data in Table 3 show clearly that, pre-planting soaking cloves in solutions of $\mathrm{Mn}, \mathrm{Zn}$ or $\mathrm{Cu}$ resulted in significant increments in $\mathrm{N}, \mathrm{P}$ and $\mathrm{K}$ content of leaves and bulbs compared with the control treatment during both seasons of study. Generally, the highest N, P and K content of leaves and bulbs were resulted by using $\mathrm{Cu}$ lonely at the concentration of $400 \mathrm{ppm}$, especially in 
the first season, followed by the treatment which contains a mixture of 1000 ppm $\mathrm{Mn}+400 \mathrm{ppm} \mathrm{Cu}$ particularly in the second season. The simulative effect of micronutrients on leaves mineral content may be due to the increasing effect of tested micronutrients on plant growth and plant metabolic processes and this may led to higher accumulation of the studied leaf minerals, i.e. $\mathrm{N}, \mathrm{P}$ and $\mathrm{K}$ (Gamili, 1987 and Abd El-Dayem and Badr, 1992).

Similar findings were reported by Abed et al. (1988) and El-Zohery (2004) on garlic and Ibrahim et al. (1980a) and El-Mansi and Sharaf El-Dien (2005) on onion.

\section{3- Effect of the interaction between cultivars and micronutrients:}

Data in Table 3 show that the maximum increments of $\mathrm{N}, \mathrm{P}$ and $\mathrm{K}$ percentage in both leaves and bulbs of Balady cv. were obtained as a result of using mixture of $1000 \mathrm{ppm} \mathrm{Mn}+400 \mathrm{ppm} \mathrm{Cu}$, meanwhile in Chinese cv. by using combination between $1000 \mathrm{ppm} \mathrm{Mn}+500 \mathrm{pmm} \mathrm{Zn}$ compared with other treatments. These findings are true during both seasons of study These results are agree with those reported by Abou-Grab et al.(1993) and El-Shobaky and Abd El-Mageed (2001) on different vegetable crops.

\section{c-Yield and its components: \\ 1- Effect of cultivars:}

Data in Table 4 reveal that Balady cv significantly produced higher number of cloves, while the Chinese cv. had heaviest clove weight, fresh weigh of bulb, cloves and dry matter percentage per bulb. These results are true during both seasons of study. The varietal differences between cultivars may be due to the specific genetic constitution of each cultivar (Dushmukh and Deore, 1990). Obtained results are in confirmity with those reported by Maksoud et al. (1987), Mangal et al. (1990) and El- Sayed (2004) on garlic.

\section{2- Effect of micronutrients:}

Data presented in Table 4 show that, per-planting soaking cloves in solution contains $\mathrm{Cu}$ at $400 \mathrm{ppm}+1000 \mathrm{ppm} \mathrm{Mn}$ or $500 \mathrm{ppm} \mathrm{Zn}$ during the first season or $1000 \mathrm{ppm} \mathrm{Mn}+500 \mathrm{ppm} \mathrm{Zn}$ in the second one recorded mostly the maximum increase compared with the other treatments in all studied yield characters. The simulative effect of copper on yield may be due to that copper may increase dry weight of bulb and total dry weight/plant (El-Mansi and Sharaf El-Dien, 2005). The increase in total yield and its components may be owing to the positive effect of these micronutrients on vegetative growth parameters (Table 2) and its chemical composition (Table 3) that followed by a good storing process of nutritional substances in the cloves (Table 5 and 6) and consequently increased bulbs yield. These results are in accordance with those reported by Abdel- Ati et al. (1993), Hassan et al. (1993), El-Zohery (2003) 
and Abd-El-Moneem et al. (2005) on garlic and Havlin et al. (2007), El-Tohamy et al. (2009) and Alam et al. (2010) on onion.

\section{3- Effect of the interaction between cultivars and micronutrients:}

Data in Table 4 indicate that Balady $c v$. gave the highest values in most studied characters during the two growing seasons by soaking cloves preplanting in solution contained $500 \mathrm{ppm} \mathrm{Zn}+400 \mathrm{ppm} \mathrm{Cu}$ followed by the treatment which contained $1000 \mathrm{ppm} \mathrm{Mn}+400 \mathrm{ppm} \mathrm{Cu}$. In this respect, Chinese $c v$. achieved most maximum values by using solution contained $1000 \mathrm{ppm} \mathrm{Mn}+500 \mathrm{ppm} \mathrm{Zn}$ and came in the first rank followed the treatment contained $1000 \mathrm{ppm} \mathrm{Mn}+400 \mathrm{ppm} \mathrm{Cu}$.

Obtained results are in agreement with those found by El-Sawah (1990), Hassan et al. (1993), Ayman (2002) and El-Zohery (2003) on garlic and Bhonde et al. (1995), Mattew et al. (2000), Havlin et al. (2007) and Alam et al. (2010) on onion.

\section{d- Bulb quality: \\ 1- Effect of cultivars:}

Data presented in Tables 5 and 6 reflect significant differences among Balady and Chinese $c v s$ in all studied bulb quality characters, i.e., $\mathrm{N}, \mathrm{P}, \mathrm{K}, \mathrm{Mn}$, $\mathrm{Zn}$ and $\mathrm{Cu}$ contents and total carbohydrates as well as total soluble solids percentages of cloves in both seasons. Balady cv. significantly surpassed Chinese cv. concerning all studied variables except T.S.S. \% which showed opposite trend during the two seasons. As this regard, Dushmukh and Deore, (1990) reported that such differences may be due to the specific genetic constitution of each cultivar. Moreover, Nurzynska and Wierdak (1997) mentioned that chemical composition of garlic bulbs differ according to ecotypes and cultivars. These results are in agreement with those reported by Maksoud and El-Oksh (1983) and El- Sayed (2004), on garlic.

\section{2- Effect of micronutrients:}

Data in Tables 5 and 6 show clearly that soaking cloves in solutions of either $1000 \mathrm{ppm} \mathrm{Mn}, 500 \mathrm{ppm} \mathrm{Zn}$ or $400 \mathrm{ppm} \mathrm{Cu}$ solely or in their possible combinations as pre-planting treatments resulted in significant increments in $\mathrm{N}$, $\mathrm{P}, \mathrm{K}, \mathrm{Mn}, \mathrm{Zn}$ and $\mathrm{Cu}$ content as well as total soluble solids and total carbohydrates percentage of cloves compared with the control treatment during both growing seasons. In this connection, the highest increments in the aforementioned characters were obtained mostly as a results of soaking cloves in $1000 \mathrm{ppm} \mathrm{Mn}+400 \mathrm{ppm} \mathrm{Cu}$ followed by the treatment $1000 \mathrm{ppm} \mathrm{Mn}+500$ ppm $\mathrm{Zn}$ compared with the other used treatments. These results were true during both seasons of this study. Obtained results are in agreement with those found by Abed et al. (1988), Abd El-Hamid (1997) and El-Zohery (2003) on garlic and Allam (1999) on onion. 


\section{3- Effect of the interaction between cultivars and micronutrients:}

Data in Tables 5 and 6 illustrate that soaking cloves of Balady cv. preplanting at mixture of $1000 \mathrm{ppm} \mathrm{Mn}+400 \mathrm{ppm} \mathrm{Cu}$ gave mostly the highest values of chemical bulb quality followed by the treatment $1000 \mathrm{ppm} \mathrm{Mn}+500$ ppm Zn .

As for Chinese $c v$., all studied characters were recorded the maximum increase compared with the other treatments by using the mixture of $1000 \mathrm{ppm}$ $\mathrm{Mn}+500 \mathrm{ppm} \mathrm{Zn}$ except $\mathrm{Zn}$ content and carbohydrates percentage which showed the highest values by the treatment $1000 \mathrm{ppm} \mathrm{Mn}+400 \mathrm{ppm} \mathrm{Cu}$. Obtained results are in conformity with those reported by Ismail (1995) on garlic, Allam (1999) on onion and El-Shobaky and Abd El-Mageed (2001) on Pea.

\section{e-Storageability:}

\section{1- Effect of cultivars:}

Data in Tables 7 and 8 clearly show that there were significant differences among Balady and Chinese cultivars with regard to storage potential could be detected. In this respect, data in Table 7 show that Chinese cv. Gave the least weight loss percentage of garlic bulbs during storage period as compared with Balady cv. Furthermore, the percentage of weight loss was increased as storage time increased, the highest percent of weight loss was noticed after 6 months from harvest. These results were true in the two seasons of study. In this concern, numerous investigators demonstrated the major factors affecting bulbs weight loss during storage period such as desiccation, respiration, physiological losses in weight, rotting losses and sprouting losses (Kale et al., 1991 and El-Kafoury et al., 1996). Obtained results are in conformity with those found by Shahien (1992), Nurzynska and Wierdak (1997) Aly et al.(2004) and El- Sayed (2004), on garlic.

Moreover, data in Table 8 demonstrate that garlic bulbs of both Balady and Chinese cultivars were satisfactorily stored without any infection or rot diseases in the first month during both growing seasons. The percentage of infection and rot diseases increased gradually with the time of storage from the second month up to the six month which recorded the maximum values. The higher percent in this respect was observed in Balady cv. than Chinese cv. These results might be due to the biochemical changes in cloves contents such as increasing sugars and or/decreasing volatile and phenolic compounds which enhanced cloves invasion by pathologenic fungi (Ragab et al., 1984). In addition, Bottcher and Gunther (1994) reported that antimicrobial materials from cloves predisposed to infection by many pathogenic fungi. On the other hand, the lower percentage of decay during storage period in cloves of Chinese cv. may be due to the higher dry matter content showed in Table 2 as compared with those of Balady cv. (Nassar et al., 1972 and Fouda et al., 1977). Obtained 
results are in agreement with those found by Aly et al. (2004) and El- Sayed (2004) on garlic.

\section{2- Effect of micronutrients:}

Data presented in Table 7 show that soaking cloves pre-planting in 400 ppm $\mathrm{Cu}$ solely or mixed with $500 \mathrm{ppm} \mathrm{Zn}$ recorded the least weight loss percentage of garlic bulbs during storage period. On the other hand, beside control treatment and $\mathrm{Mn}$ alone at $1000 \mathrm{ppm}$, maximum weight loss percentage was observed also by the mixture of the three micronutrients used i.e., 1000+500+400 ppm manganese, zinc and copper, respectively. Such results were true during both seasons of study. These results may be due to the main role of $\mathrm{Cu}$ as micronutrient necessary for bulbing crops and its effect on thickness of storage leaves and its effect on respiration and water loss rate (ElZohery, 2003). Moreover, Marschner (1995) reported that copper affects the formation and chemical composition of cell wall which in turn affects lignification and this may decrease weight loss percentage of garlic bulbs. Obtained results are in agreement with those reported by Ayman (2002) and ElZohery (2003)on garlic and El-Mansi and Sharaf El-Dien(2005) on onion.

In connection the infection and rot diseases percentage, data in Table 8 indicate that soaking cloves pre-planting in 500 ppm zinc combined with 400 ppm $\mathrm{Cu}$ or the last one singly recorded the least values.

These results may be attributed to that such micronutrients induce systemic resistance against the pathogen (Conti et al., 1994 ) and are confirmed by those obtained by Abd-El-Moneem et al. (2005) on garlic, Mukesh-Kumar and Kumar (1999) on onion .

\section{3- Effect of the interaction between cultivars and micronutrients:}

Data presented in Tables 7 and 8 reveal that Chinese cv. was more effective and showed the least weight loss as well as the infection and rot diseases percentage as compared with Balady cv., especially when cloves were soaked pre-planting in solution of either $400 \mathrm{ppm} \mathrm{Cu}$ singly or combined with $500 \mathrm{ppm} \mathrm{Zn}$. On the other hand, beside control treatment both used cultivars showed the highest percentages in this respect by using $1000 \mathrm{ppm} \mathrm{Mn}$ or the triple mixture (1000 ppm $\mathrm{Mn}+500 \mathrm{ppm} \mathrm{Zn}+400 \mathrm{ppm} \mathrm{Cu})$ comparing with other treatments. These results agree with those reported by Aly et al. (2004)on garlic.

Conclusively, it can be recommended that soaking garlic cloves for 24 hours per-planting in mixture of $1000 \mathrm{ppm} \mathrm{Mn+400} \mathrm{ppm} \mathrm{Cu}$ in case of Balady cv. or in 1000 ppm Mn+500 ppm Zn in case of Chinese cv. to obtain maximum values of most studied variables. 


\section{REFERENCES}

Abd El-Dayem, H.M.M. and E. Badr Abo El-Yazid. 1992. Response of faba bean plants (Faba vulgaris L.) healthy or infected with broad bean mosaic virus (BBMV) to foliar spray with Fe or Zn. Egypt. J. Appl. Sci., 7( 6): 27-46.

Abd El-Hamied, A. M. 1990. Studies on intercropping cultivar and planting date of garlic. Minia J. Agric. Res. \& Dev., 12 (2): 1065-1082.

Abd El-Hamid, A. M. 1997. Influence of sulphur application and some micronutrients on growth and productivity of garlic (Allium sativum L.). Minufya J. Agric. Res., 22 (2): 263-279.

Abdel-Ati, Y.Y., M.N.M. Hassan and M. M.Farrag. 1993. Studied on garlic under El-Minia growing conditions. 2- Effect of pre-planting soaking with some microelements. Minia J. Agric. Res.\& Dev., 15 (3): 823838.

Abd-El-Moneem, K.M.H., S. B.M. Fawaz, F.A. Saoeed and A. I. ElShehaby .2005. Effect of cloves size and certain micronutrients on fusarium basal rot of garlic. Assiut J. Agric. Sci., 36 (4): 163-175.

Abed, T.A., F.A. Abo-Sedera and I.O.A. El-Orabi. 1988. Effect of soaking cloves in some micro-nutrients solutions and nitrogen fertilizer soil addition on growth, yield and chemical composition of garlic plants. Ann. Agric. Sci., Moshtohor, 26 (4):2143-2161.

Abou-Grab, O.S., E.A.Y. El-Kabbany and S.H.H. Kandeel .1993. Effect of some micronutrients on growth, seed yield, photosynthetic pigments and mineral contents of onion. Egypt. J. Appl. Sci., 8 (12): 89-105.

Alam, M.N., M. J. Abdedin and M. A. K. Azad. 2010. Effect of micronutrients on growth and yield of onion under calcareous soil environment. Int. Res. J. Plant Sci., 1 (3): 56-61.

Allam, M. M. 1999. Physiological studies on productivity and storageability of some onion cultivars. Ph. D. Thesis, Fac. Agric. Cairo, Univ. Egypt. pp 301.

Aly, A. Z., Dawlat, A. Abdel Kader, A. E. A. Ismail and A. A. Soliman. 2004. Effect of some agricultural and storage practices on garlic bulbs rot diseases. Zagazig J. Agric. Res., 31 (2): 581-603.

Ancpok, P. E. 1990. Fertilization By Microelements. Leningrad Agro. Promezdat, USSR. pp 272.

Atwa, A. A., A. 1970. Physiological studies on maturity, curing, packing, transportation and storages of Egyptian onions. Ph.D. Theses, Fac. Agric. Cairo Univ. Egypt.

Ayman, K. M. 2002. Effect of foliar fertilization with micronutrients on yield and storageability of onion (Allium Cepa L.) and garlic (Allium Sativum L.) plants. The $3^{\text {rd }}$ Sci. Con. Agric. Assiut, Oct. 
Bhonde, S.R., L. Ram, U.B. Pandey and H. N. Tiwari .1995. Effect of micronutrients on growth, yield and quality of kharif onion. NewsLetter-National-Horticultural-Research and Development Foundation, 14-15 (1): 16-20.

Black, C.A. 1982. Methods of Soil Analysis. Part 2. American Society of Agronomy, INC., publisher, Madison, Wisconsin, USA.

Bottcher, H. and I. Gunther. 1994. Quality changes during long-term storage of garlic (Allium sativum L.) external quality. Nohrung, 38: 61-69.

Bremner, J.M. and C.S. Mulvaney. 1982. Total nitrogen. In: Page, A.L., R.H. Miller and D. R. Keeney (Eds). Methods of Soil Analysis. Part 2, Amer. Soc. Agron. Madison, W. I. USA, pp. 595-624.

Chapman, H. D. and P. F. Pratt. 1961. Methods of Analysis for Soil, Plant and Water. Univ. of California. Div. Agric. Sci. Priced Publication.

Conti, G.G., M. Bassi, D. Maffi, G. Violini, L. Magnani and L. Gotti. 1994. Induced systemic resistance against Sphaerotheca fuliginea in cucumber: Efficiency of tobacco necrosis virus (TNN) and copper sulphate $\left(\mathrm{CuSO}_{4}\right)$ in eliciting defence reactions. Journal of Phytopathology, 140: 123-132.

Dubois, M., K.A. Gilles, J.K. Hamilton, P.A. Robers and F. Smith. 1956. Calorimetric methods for determination of sugars and related substances. Anlyt. Chem., 28:350.

Dushmukh, V.V. and B.P.Deore. 1990. Relationship between dry matter and yield in garlic genotypes. Annals of Plant Physiology, 4 (1): 122-123.

El-Kafoury, A. K., A. K.Mostafa, M. Y. Ibrahim and A. M. Hegazy. 1996. Performance of some onion cultivars concern yield, quality, chemical constituents and storability of bulbs. J. Agric Sci. Mansoura Univ., 21(4): 1275-1285.

El-Mansi, A. A. A.and M. S. M. Sharaf El-Dien. 2005. Effect of foliar spray with boron and copper on dry weight, yield and storability of onion under sandy soil conditions. Zagazig J. Agric. Res., 32 (3): 767-791.

El-Sawah, M. H. 1990. Influence of foliarly applied $\mathrm{Cu}$ and/or $\mathrm{Mn}$ on growth and yield of garlic. Zagazig. J. Agric. Res., 17(2):411-416.

El-Sayed, M. Abd-El-Motey Abd-Ellateff. 2004. Studies on productivity of some garlic cultivars under Sinai conditions. M. Sc. Thesis, Fac. Agric., Cairo Univ., Egypt. pp 92.

El-Shobaky, S. A. and Y.T. Abd El-Mageed.2001. Response of pea plants to foliar spray with some micro-nutrients ( $\mathrm{Fe}, \mathrm{Zn}$ or $\mathrm{Mn}$ ) in the new reclaimed sandy soil. The fifth Arabian Hort. Con., Ismailai, Egypt. March 24-28. 
El-Tohamy, W. A., A.Kh., Khalid, H. M. El-Abagy and S. D. AbouHussein .2009. Essential oil, growth and yield of onion (Allium cepa L.) in response to foliar application of some micronutrients. Astrialin Journal of Basic and Applied Sciences, 3 (1): 201-205.

El-Zohery, S.S.M. 2003. Physiological studies on garlic crop. Ph D. Thesis, Faculty of Agriculture, Moshtohor, Zagazig University, Benha Branch. 160 pp. Egypt.

Fouda, S. A. , S. A. El-Baz and S. M. Moustapha. 1977. Varietals trial of garlic in Egypt. Agric. Res. Rev., 55 (3): 165-175.

Gamili, A. El. 1987. Effect of some agricultural treatments on growth, yield and chemical constituents of onion (Allium cepa L.). Ph.D. Theses, Fac. Agric. Minufya Univ. A.R.E.

Gomez, K. A. and A. A. Gomez. 1984. Statistical Procedures for Agricultural Research. $2^{\text {nd }}$ ed., John Wiely \& Sons. New York.

Hassan, M. N. M., Y. Y. Abdel-Ati and M. M. Farrag. 1993. studies on garlic under El-Minia growing conditions. 3- Effect of foliar application with some microelements on the growth and yield of two cultivars. Minia J. Agric. Res.\& Dev., 15 (3): 839-859.

Havlin, J. L., J. D. Beaton, S. L. Tisdale and W. L. Nelson. 2007. An introduction to nutrient management. Soil Fertility and Fertilizers, pp 244-289.

Ibrahim, I. A., M. H. Mahmoud and M. A. Ashoub .1980a. Importance of some micronutrients in the production of onion. 1- Effect of soaking onion transplants in zinc and manganese solution on some onion bulb components. Ann. Agric. Sci. Moshtohor, 14 (1):87-93.

Ismail, R.H.A. 1995. Response of garlic to some nutrients under calcareous soil condition. M. Sc. Thesis, Fac. Agric. Cairo Univ. Egypt. pp 246.

Jackson, M. L. 1970. Soil Chemical Analysis. Prentic Hall, Inc. Englewood Cliffs, New Jeresy, pp 498.

Kale et, P. N., S.D. Warade and K. B. Jagtap. 1991. Evaluation of tropical onion germplasm for better storage quality. Onion Newsletter for the tropics, 3: 27-29.

Maksoud, M. A. and I.I. El-Oksh. 1983. Development growth changes in garlic. Egypt. Journal of Hort., 10 (2): 131-142.

Maksoud, M. A., M. A. Beheidi, A. A. Gad, M. A. Khalil, E. A. ElGhamriny and M. A. Saad. 1987. Evaluation of three garlic cultivars under complet fertilizer treatments. Zagazig J. Agric. Res., 14(2): 62-83.

Mangal, J. L. , R. K. Singh, A. C. Yadav, S. Lai and U. C. Pandey. 1990. Evaluation of garlic cultivars for salinity tolerance. J. Hort. Sci., 65 (6): 657-658.

Mann, L. K. 1952. Anatomy of garlic bulb and factors affecting bulb development. Hilgardia, 21: 195-231. 
Marschner, H. 1995. Mineral Nutrition Of Higher Plant. $2^{\text {nd }}$ ed., Academic Press. Limited. Text Book. pp 864.

Mattew, L. A., A.N. Wedell, D. P. Willium and H. P. John. 2000. Micronutrient status. Agron. J., 92: 261-268.

Mukesh-Kumar, D. K. Das and M. Kumar. 1999. Yield and storage- life of onion (Allium cepa L.) as affected by zinc and sulfur application. Environment and Ecology, 17(3): 580-584.

Nasreen, S., M. N. Yousuf, A. N. M. Mamun, S. Brahma and M. M. Haquc. 2009. Response of garlic to zinc, boron and poultry manure application. Bangladesh J. Agric. Res., 34(2):239-245.

Nassar, S. H., S. Moustafa, M. Fouda and S. Ghebrial. 1972. A better grlic varity for export. Agric.Res.Rev., 50: 47-58.

Nurzynska and R. Wierdak. 1997. Changes in chemical composition during garlic storage under different conditions. Annuals Univ. Mariae Curie Sklodowska Sectio (C.F., Hort. Abst., 6: 9-16, 1998).

Olsen, S.R. and L.E. Sommers. 1982. Phosphorus In : Methods of Soil Analysis, Part 2. Amer. Soci. Agron., Madison, W.I.USA, pp. 403-430.

Ragab, M. M., M. A. Kararah, M. E. Osman and M. A. Mostafa. 1984. Effect of infection with Fusarium salani on garlic cloves with special reference to the biochemical changes. Egypt. J. Phytopathol., 16 (1-2): 23-33.

Sauchelli, V. 1969. Trace Elements In Agriculture. Van Nastrend Remhold Co., London, Toranto, New York, Melboune, USA p245.

Shahien, M. M. 1992. Morphological and physiological studies on some garlic ecotypes. M. Sc. Thesis, Fac. Agric. Cairo Univ.

Simis, J. L. and W. H. Patrick. 1978. The distribution of microelements cations in soils under conditions of varying redox potential and $\mathrm{pH}$. Soil Sci. Soc. Am. J. , 42: 258-262.

Zaki, M. A. 1984. Effect of some agricultural treatments of garlic plants. M. Sc. Thesis, Fac. Agric. Zagazig Univ., Egypt.

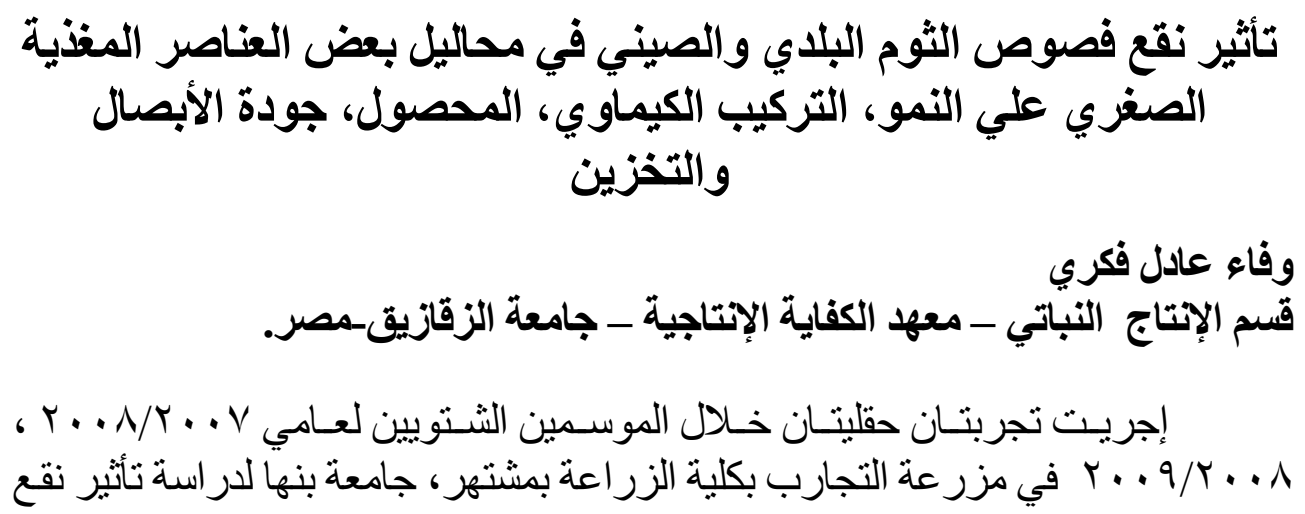




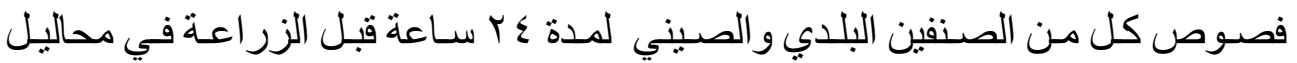

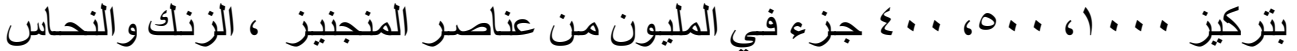

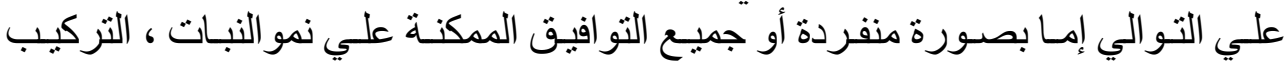
الكيماوي، المحصول، جودة الأبصال و القدرة التخزينية. وقد اوضحت النتائج التي تم الحصول عليهابها الآني:

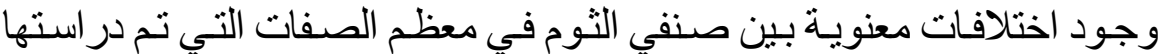

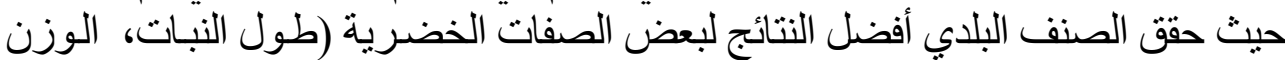

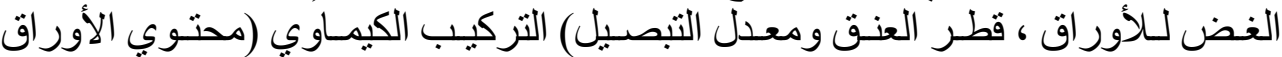

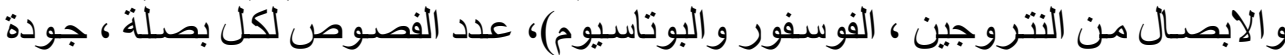

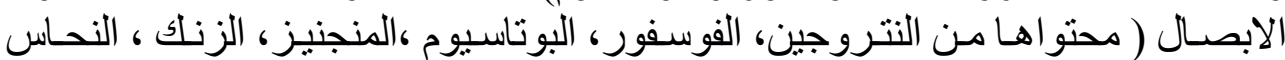

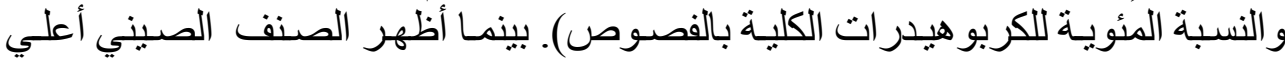

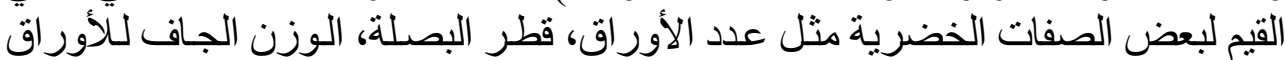

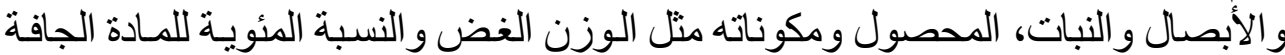

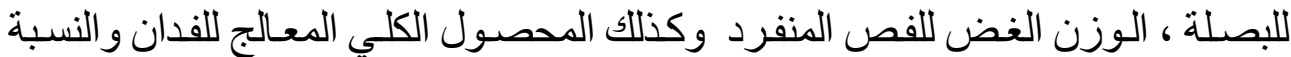

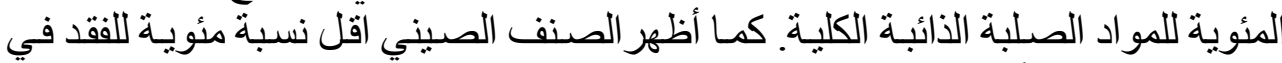

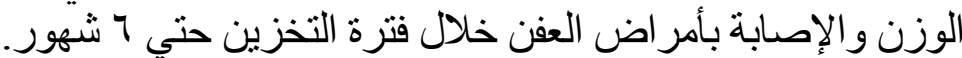

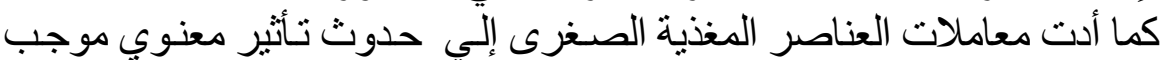
علي جميع الصفات التي تم در استها.

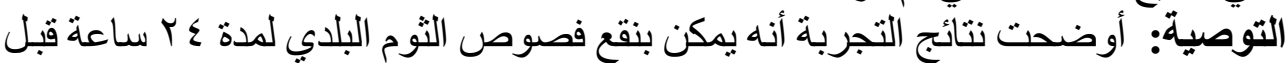

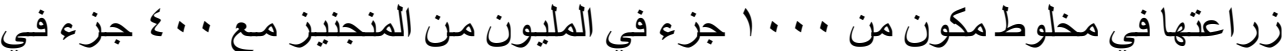

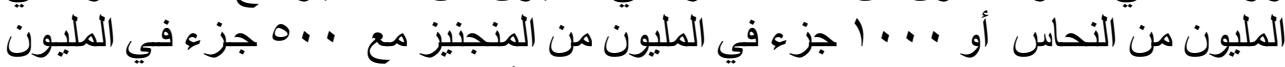

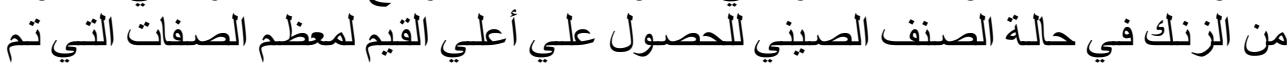

